\title{
Competition Policy under Economic Recessions: Historical Changes and Implications*
}

\author{
Pinguang Ying \\ School of WTO Research and Education, Shanghai Institute of Foreign Trade, Shanghai, China \\ Email: yingpinguang@foxmail.com
}

Received December 9, 2012; revised January 10, 2013; accepted February 11, 2013

\begin{abstract}
Before the current financial crisis, economic recessions in history were always accompanied by relaxation or abandon of competition policy. However, in the current financial crisis, although different jurisdictions have different practices, most jurisdictions have kept the bottom line of competition policy enforcement. Such historical transformation roots in deep reflections on historical failures and the popularization of competition policy as well as the strengthening of the competition authorities. China is one of the few countries still weakening competition policy enforcement during the current financial crisis. In fact, there are several mechanisms contained in competition laws and policies, such as the exemption of cartels, the defense of business concentrations and the coordination between competition authorities and sector regulators, which provide some space of flexible competition policy enforcement during economic recessions. Considering China's short history of competition policy enforcement and consistent tradition of government intervention in economy, it is strongly advised to hold on the bottom line of competition policy and pay more attention to government-led anti-competitive conducts during economic recessions.
\end{abstract}

Keywords: Competition Policy; Economic Recessions; Flexible Enforcement; Coordination Mechanism

\section{Introduction}

The financial crisis triggered by the US subprime loan problem quickly swept through the world, and many countries have introduced various economic stimulus plans to promote economic recovery. In such a special background, whether the enforcement of competition policy should be relaxed or suspended to the industrial policy or other economic policies, has already been a problem placed before governments of all countries. Outwardly, the governments' intervention all over the world was continuously strengthened under the current situation, and even the nationalization has become a powerful instrument to save crisis. Therefore, the relaxation or abandon of competition policy seems to be an inevitable choice. Just as Daniel Crane said, "antitrust seems to be a luxury that (a) country cannot afford in any crisis [1]." However, during the current financial crisis, although the competition policy enforcement in different jurisdictions revealed different versions, it is incredible that there were no signs of all-round relaxation of competition policy all over the world. In some countries, such as the United States, the competition policy enforcement has even been strengthened. This abrupt change of attitudes on compe-

${ }^{*}$ This article was sponsored by the 085 Subject Highland High-Level Talent Team Construction Project. tition policy enforcement under the current economic recession has attracted much attention in academia.

However, many people (especially in China) still insists on that the competition policy enforcement during economic recessions should be relaxed or abandoned, or at least the competition policy enforcement should give way to the industrial policy. This paper refutes this point of view from the history and reality angles, and puts forward some general advices on the competition policy enforcement during economic recessions after comparing diverse choices of competition policy by distinct jurisdictions during different economic recession periods.

It is the basic focus of this paper that how competition policy should respond to cyclical changes of economy, especially in the special circumstances of economic recession. Starting from this perspective, the article will firstly compare the choice of competition policy among different jurisdictions under economic recessions in the history and their enforcement performance, and then analyze the similarities and differences of competition policy among major countries and regions during the current financial crisis and their causes. Finally, it will put forward some general advices on the choice of competition policy under economic recessions after comparing and analyzing the mechanism and logic behind the shift of competition policy enforcement. 


\section{Comparison of Competition Policy under Economic Recessions in History}

From the perspective of historical comparison, it can be concluded that competition policy during economic recessions in history shows two distinctive characteristics: on the one hand, economic depressions in history were always accompanied by the compromise of competition policy with no significant differences among different jurisdictions; on the other hand, in the current financial crisis, different countries followed a personalized or even opposite route in competition policy enforcement. The following text will first make a comparative study on the changes of competition policy before and in the current financial crisis and then compare the different situations of competition policy enforcement among different jurisdictions under the current financial crisis.

\subsection{Competition Policy under Economic Recessions before the Current Financial Crisis}

Before the Second World War, there were only a few countries, such as the United States and Canada, had competition laws. Therefore, in quite a long period of time, cartels and trusts were not the subjects being blamed. On the contrary, they were good things in public eyes to avoid disorder competition and keep social stability. In some economists' opinion of that time, cartel was able to ease the pressure of "creative destruction" of competition, and it was inevitable to take cartels to adjust production in a period of demand fluctuation [2]. In such a background, confronting economic recessions, for those we may seem as illegal anti-competitive behaviors today, people of then may regard them as means of saving crisis instead.

For example, the 1929-1933 economic depression is one of the worst economic recessions in the history of the United States and the Europe. When exploring reasons and resolutions to economic recessions, later generations would almost all trace back to this depression. However, the period of the Great Depression and the Franklin Roosevelt's New Deal also was an important period of competition law enforcement decline in the history of the United States and the Europe. The distrust to free market and the rise of state intervention theory at that time, all prompted the government to reconfigure resources and achieve economic recovery by means of direct intervention. One of the important performances is that various countries enacted laws to tolerant or even encourage cartels and monopolistic behaviors. For instance, Italy in 1932 promulgated the Law concerning the Compulsory Establishment of Cartels and their Activities, Germany in 1933 published the Law on the Establishment of Compulsory Cartels, the United States in 1933 issued the Na- tional Industrial Recovery Act, and then established the National Recovery Administration to help industries to establish and execute a variety of "industry rules", while these rules were actually monopoly agreements limiting price, production, investment and market access [3]. More surprisingly, the competition authorities at that time not only did not investigate this kind of behaviors, but provided assistance to carry out these monopoly agreements with other government branches. These government intervention measures during the New Deal once encountered strong resistance from the Federal Supreme Court. For example, from 1935 to 1937, the Federal Supreme Court made 13 judgments announcing related New Deal legislation unconstitutional [4]. However, in the face of economic depression and the government's constant pressure [5], the Federal Supreme Court finally had to back down and relax the competition law enforcement. For instance, in the Appalachian Coals v. US, the Federal Supreme Court suddenly applied the rule of reason to analyze the price agreement rather than the rule of per se illegal that was always applied before, and finally concluded that "the common sales agreement signed between coal producers is legitimate" [6].

Similarly, there was only an anti-monopoly law in Europe before the Second World War that was the Regulations to Prevent the Abuse of Economy Power (RPAEP) of Germany. However, the Great Depression also led to great changes in the forms and functions of the RPAEP. In 1930, the RPAEP was modified by an emergency legislation, which completely canceled the function of the cartel court to dispose of anti-competitive disputes and transferred the power of dispute settlement to the Ministry of economy. When the Nazi government came in, the RPAEP was distorted even more by regarding cartels as a way of resource allocation [7]. Also, in the United Kingdom, before the Second World War, cartels were generally regarded as legitimate business activities. In fact, in Britain, cartels had never been prohibited by the government before the Second World War, and in 1930s they were even encouraged and promoted [8].

As the United States and the Europe, when facing economic recessions, Asian countries in the history were also inclined to disregard competition policy. In addition, because of the feature of strong government, it was more likely to implement anti-competitive behaviors by the governments themselves in Asia. For example, facing the economic recession after the First World War, Japan once formulated laws to strengthen cartels for small and medium-sized enterprises. In 1931, according to the Law on the Control of Key Industries, Japan promoted cartelization among enterprises. In 1933, Japan formulated the Doctrine on the Management of Foreign Exchange, by which the free competition was eliminated and the controlled market policy was implemented [9]. 
In the following decades after the Second World War, European countries such as Britain, Belgium, Austria, Denmark, Switzerland and the Netherlands, Asian countries such as India, South Korea and Thailand, and African and American countries such as South Africa, Brazil and Chile, etc., all promulgated competition laws. In the 1990s, this trend swept through developing countries and transition countries such as Czechoslovakia, Hungary, Kazakhstan and Russia. So far, there are more than one hundred jurisdictions having competition laws. However, considering that these laws were mostly the products of external forces or the target of developing economy, there is still a long distance for these laws to enter into their own competition culture. Therefore, in the face of economic recessions, these jurisdictions still tend to relax competition law enforcement for a long period of time.

For instance, as one of the victorious nations, the United States exerted an important influence on the competition laws of the European and Asian countries after the Second World War. Under US pressure, Japan issued the Act on Prohibition of Private Monopolization and Maintenance of Fair Trade (hereinafter referred to Japan Anti-monopoly Law) in 1947, and Germany passed the Act against Restraint of Competition (hereinafter referred to Germany Anti-monopoly Law) in 1957. The Rome Treaty signed in the same year also provided relevant provisions banning anti-competitive agreements and the abuse of dominant market position. But these laws almost all left extensive spaces for the relaxation of law enforcement during economic recessions by the way of exemption. The most typical example is the Germany Anti-monopoly Law which provided nine cartels that can be exempted. Until its revision in 1999, most of these exemptions were finally abolished.

Likewise, although Japan formulated the Japan Antimonopoly Law under the pressure of the United States and took a general position to ban monopoly, the number of cartel exemptions were gradually increased by the excuse of economic recessions. In addition, Japan issued a series of measures to promote and strengthen cartels in the area of foreign trade, industry, agriculture, forestry, fishery, transportation, insurance as well as small and medium-sized enterprises [10]. For instance, after the end of the Korean War, a large number of Japanese enterprises faced with survival crisis because of the extremely atrophy of the domestic market. In order to rescue these enterprises in difficulties, the Japan Ministry of International Trade and Industry decided in 1952 to persuade the industries of cotton textile and chemical fiber textile to decrease production, while Japan Fair Trade Commission (JFTC) ultimately tolerated these conducts [11]. For another example, after the outbreak of Southeast Asian financial crisis in 1997, South Korea has carried out a series of economic reform, including the government's di- rect intervention in the operation of financial institutions. For instance, the financial institutions with the capital adequacy ratio less than $8 \%$ were identified as problematic and were cleaned up by ways of nationalization, mergers and termination of business [12]. This actually evaded the merger control rules of the competition law and formed a direct intervention to the enterprises' mergers and reorganizations.

\subsection{Different Versions of Competition Policy under the Current Financial Crisis}

In the current financial crisis, almost all governments have introduced a series of economic rescue plans to stimulate economy. For instance, the United States has issued the Housing and Economic Recovery Act, the Emergency Economic Stabilization Act and the American recovery and Reinvestment Act, the European Union has adopted a European Economic Recovery Plan, and China has injected the market with a four-trillion bailout and launched ten Programs to adjust and reinvigorate key industries. These economic stimulus plans always contained more or less contents of restricting competition. However, contrary to the situations in the history, at this time competition policies in many jurisdictions have played a crucial role in keeping these plans and programs fair and competitive. In general, most of jurisdictions basically kept the bottom line of competition policy although that the different jurisdictions had different versions of competition policy enforcement.

By investigating the competition policy enforcement in main jurisdictions in the current financial crisis, four categories of competition policy enforcement can be summarized as follows.

The first category is represented by the United States and Japan in which the competition policy is enforced strictly. In the United States, for example, on April 13, 2009, the Antitrust Division (AD) of the Department of Justice launched an Economic Recovery Initiative that targets potential fraud and collusion related to any stimulus spending [13]. Just as Carl Shapiro, the Deputy Assistant Attorney General for Economics of the AD said, "the AD's short answer is this: keeping market competitive is no less important during times of economic hardship than during normal times [3]." The anti-trust enforcers in US did not show the slightest retreat facing with a succession of economic stimulus plans introduced by the US Government. By careful observation, it can be found that the competition policy enforcement under the Obama administration has shown a visible tendency of reinforcement. While a candidate, President Obama committed that if elected, he would instruct his administration "to reinvigorate antitrust enforcement [14]." The Department of Justice (DOJ) and the Federal Trade Commission (FTC) under the Obama administration are also 
filled with people who are inclined to enforce antitrust laws aggressively. The AD of DOJ has been considered as a conservative enforcer in the past eight years. However, under the lead of Christine Varney, this antitrust authority has begun to move towards a direction of more rigorous enforcement of antitrust laws. In a most typical example, no more than fortnight since she was newly appointed, Christine Varney announced the withdrawal of a report named Competition and Monopoly: SingleFirm Conduct under Section 2 of the Sherman Act, which was issued by the last administration of the AD. According to Varney, the report "raised too many hurdles to government antitrust enforcement and favored extreme caution and the development of safe harbors for certain conduct within reach of Section 2 [15].” Therefore, in the United States, the competition policy enforcement under the financial crisis did not have the slightest relaxation. Instead, in the face of various economic stimulus plans, the competition policy has always played a crucial role in ensuring economic stimulus plans free from anticompetitive or fraudulent conducts.

Similarly, during the crisis, Japan modified the Japan Anti-monopoly Law which took effective in January 2010. By this modification, the Japan Anti-monopoly Law expanded the types of conduct subject to surcharges. Before this expansion, the surcharges were only limited to rig bidding and cartels, and the objects levied were mostly the construction businesses and large manufacturers. After this modification, the illegal behaviors of the service industry would also be punished. Besides, The abuse of superior bargaining position, which usually conducted by large enterprises to force contractors to trade with them unequally, and the exclusionary types of private monopolization such as dumping at the price lower the cost, would also be fined. In addition to the more severe legislation, the judicial enforcement of competition policy also revealed a tight trend. For instance, in October 2009, JFTC imposed a total sum of 3.321 billion yen as fines for three companies affiliated to the Japan's Panasonic Group, and a company affiliated to the Korea's Samsung Group and a company of the LG Group, alleging that they violating the Japan Anti-monopoly Law by concluding a price alliance in the sale of TV picture tube [16]. This was the first time JFTC commanded foreign enterprises to pay fines for suspected price alliance.

The second category is represented by the European Union in which the principles and rules of competition policy remain unchanged, but the implementation of such principles and rules are flexible. Since the outbreak of the financial crisis, EU members have introduced a series of state aid schemes supporting financial stability in such means as recapitalization and asset purchase guarantee. In order to deal with the special situation during the financial crisis, the European Commission in October 2008 also issued a Communication which gave clear guidance on how the Commission would apply the Treaty rules to state aid schemes [17]. In February 2009, according to the actual implementation of state aid rules under the specific situation, the European Commission issued a revised Communication [18]. However, the review of state aid schemes more or less reflected a flexibility of competition policy enforcement in the EU. For instance, the Commission has quickly approved a number of state aid schemes supporting financial stability, including guarantee schemes advanced by Denmark, Finland, Portugal, Ireland, Netherlands, Sweden, France and Italy, a recapitalization scheme from Spain, as well as a package of aid schemes brought forward by Germany, the UK and Greece, etc [19]. Besides, although the Commission intended "to continue applying the existing (merger control) rules" in the framework of crisis, the existing rules also "allow the Commission to permit takeovers to be implemented without having to wait for the Commission's approval in cases where there is urgency and where there are no 'a priori' competition concerns [20].” Furthermore, although the Commission has little possibility to reduce the duration of the examination of merger control notifications, it may display some flexibility with respect to the scope of the information to be provided by merging parties [21]. This would actually speed up the implementation of a merger, and to some extent become a part of the state aid schemes. Overall, the competition policy enforcement in the EU level basically adheres to the following two policy options: First, ensure consistency and stability in the principles and rules relied on to assess the competition issues arising in relation to the financial crisis in a bid to prevent harms and distortions in the EU single market. Second, grant competition policy enforcers sufficient flexibility in the implementation of those principles and rules with a view to provide the Commission and the member countries with the greatest likelihood and legal space to get involved with the management of the crisis.

The third category is represented by the United Kingdom in which the competition policy is modified to adapt to a flexible enforcement. The major changes in the British competition policy embodied in the amendment of the Enterprise Act 2002, which made the "stability of the UK financial system", along with the national security, become the public interest considerations that are clearly enumerated in the Enterprise Act 2002. It highlighted the voice of the Secretary of State in financial-related merger cases, and indirectly undermined the authority of the Office of Fair Trading (OFT) and the Competition Commission (CC) in the competition policy enforcement. The whole affair originated in the acquisition of HBOS by Lloyds TSB Group. The deal was negotiated and agreed in the context of the financial crisis in mid-September. The OFT considered that this acquisition was likely to 
create a so-called "relevant merger situation" warranting further inquiry by the CC. However, in the meantime, the government introduced a bill providing for the "stability of the UK financial system” as a special public interest consideration to be incorporated into the Article 58 of the Enterprise Law 2002. The bill was ultimately passed by Parliament. Under the new provision, the Secretary of State decided not to refer the merger case to the CC for further inquiry. In a nine page decision [22], the Secreary of State, Lord Mandelson, cited a large number of submissions made from the Bank of England, the Financial Services Authority and the UK Treasury to explain the benefits of the stability of the UK financial system arising from this deal outweigh the potential anticompetitive effects resulted from the merger, which was therefore deemed to be in the public interest. The revised Enterprise Law 2002 to some extent reflects the different attitudes in the competition policy enforcement between the OFT and the Financial Services Authority. The question now is whether the Secretary of State in the future will depend on the revised Article 58 to assert its authority of intervention in merger cases, and whether the "special consideration" of financial stability will give rise to a profound impact in the competition policy enforcement.

The final category is represented by China in which the competition policy enforcement is fully relaxed. Among all big countries, China is one of the minorities continued to ease competition policy enforcement during the financial crisis. In response to the financial crisis, the Chinese government also has introduced a series of policy measures, among which the most prominent were the programs to adjust and reinvigorate ten key industries. In most of these programs, the consolidation and concentration of enterprises were deemed as an effective approach to cope with the financial crisis. For example, the Petrochemical Industry Adjusting and Reinvigoration Program provides for "promoting large-scale petrochemical groups to carry out strategic cooperation... supporting powerful enterprises to carry out $\mathrm{M} \& \mathrm{~A}$ and reorganization, to expand industrial scale, and to make high-end petrochemical industry much stronger”. By careful study, it can be found that China's industrial reinvigoration programs were marked with a typical "government-led" character. The economic growth is promoted by choosing key industries and providing them with preferential policies rather than furnishing a fair and orderly competitive environment. In addition, confronting a large number of government-led anticompetitive behaviors, the competition policy enforcers have taken no action. For example, on April 24, 2009, the Ministry of Industry and Information Technology issued an Emergency Notice with regard to the Curbing of Excessive Output Growth in the Iron and Steel Industry [23], in which the output control is imposed as the primary task of the iron and steel industry.
This is a typical behavior of restricting competition. For another example, China Unicom and China Network Communications, as two big state-owned companies in the communication industry, had been consolidated in 2008, but until now have not applied to the Ministry of Commerce for merger review. On September 2, 2008, the Shanxi Province issued some measures with regard to the Acceleration of Mergers and Reorganizations of Coal Mining Enterprises [24]. These measures demanded that until the end of 2010, the number of coal mining enterprises within the Shaanxi Province ought to be reduced to no more than 1500. According to these measures, the local state-owned enterprises will naturally become the main body to promote mergers and reorganizations, and many private coal mining enterprises will be forced out of the market. The expansion of all these state-owned enterprises is not the result of market competition, but resulting from the policy arrangement and resource monopoly. It can be said that currently in China, as government-led industrial policy always prevails, the competition policy has not played the role it was supposed to be.

\section{Reflections on the Historical Changes of Competition Policy}

The great changes of competition policy mentioned above raise two questions: First, why the economic recessions in history were always accompanied by suspension of competition policy while many jurisdictions have now changed this regular practice during the current financial crisis? Second, why were there different competition policy enforcement practices in different countries during the current crisis? The following text will try to look for the answers to these two questions.

\subsection{The Reasons for the Changes of Competition Policy}

This change is not accidental, but has deep historical reasons. Outwardly, in order to alleviate economic recessions and restore market confidence, the emergency relief seems to be inevitable. Therefore, seemingly there lies a significant reasonableness in times of crisis to make the competition policy give ways to other economic stimulus policies. Nevertheless, increasing people began to reconsider the adverse effects of the inaction of competition policy enforcers during recession periods, and this reconsideration made the US and EU take a totally different attitude toward competition policy in the current crisis.

For example, after the end of the Franklin Roosevelt's New Deal, people once praised it bring great contributions to the economic recovery. However, with the passage of time, more and more people begin to believe that Roosevelt and the New Deal extended the great depress- 
sion [25]. Some people believe that the "New Deal cartelization policies are a key factor behind the weak recovery (during 1934-1939), accounting for about 60 percent of the difference between actual output and trend output [26]." Neelie Kroes, the Commissioner of the European Council, pointed out that "the suspension of the antitrust laws in the framework of the New Deal had the effect of prolonging the Great Depression by an extra seven years [27]." Christine Varney, the Assistant Attorney General of US DOJ, also argued that "antitrust must be among the frontline issues in the Government's broader response to the distressed economy. Antitrust authorities-as key members of the Government's economic recovery team-will therefore need to be prepared to take action [28]." Similarly, in Asia, some scholars have held that it is the lack of competition laws and excessive rely on industrial policy led to the 1997 Asian financial crisis [29].

All these changes show that increasing people begin to realize the function of competition policy as a firewall to economical operation. During the period of economic downturns, because of the reduction of market opportunities, the business operators in order to maintain operating profits will be more motivated to achieve collusion and coordination; the enterprises possessing a dominant market position in order to fight against competitors will be more inclined to carry out exclusive monopolistic conducts; crisis also provided a good excuse for mergers and acquisitions. All of these-monopoly agreements, abuse of dominant market position and business concentration that would lead to the impairment of competition, will impede rather than promote effective economic growth. In addition, industry policy is easy to lead to serious structural defects if there were no restrained force such as competition policy to form checks and balances. Under the continuing economic growth, economic structural contradictions may be covered. But once encountering the impact of economic crisis, masked structural contradictions will spread rapidly and cause recessions. Therefore, the relaxation of competition policy during crisis may pay a high price for the economy to recover.

Moreover, the changes of competition policy are also linked to the significant upgrade of status of competition policy in many countries. A typical example is that the range of cartel exemptions has been narrowed continuously. As mentioned earlier, in order to cope with recessions, most antitrust laws have provided exemptions for specific cartels. For instance, the Germany Anti-Monopoly Law of 1957 once stipulated nine cartels that can be get exempted. But with the development of science and technology as well as the changes of economic conditions, in 1998, Germany modified the Germany Anti-Monopoly Law by deleting exemption for rebate cartel. In 2005, the exemption for recession cartel was deleted, too.
Japan is another example. The exemption for recession cartel was first introduced in 1953. However, such exemption was comprehensive abolished by 1999 .

More importantly, competition authorities have an increasing voice in economic decision making. For example, Article 63 of the Monopoly Regulation and Fair Trade Act of Korea (Korea Anti-Monopoly Law) provides that "the chief officer of the competent administrative authority shall consult with the Fair Trade Commission in advance when wishing to propose legislation or amend enactments containing anti-competitive regulations". In practice, Korean Fair Trade Commission (KFTC) has achieved great success in effective prevention of anti-competitive regulations. Besides, there is a competition evaluation system in South Korea by which KFTC reviews regulations issued by other government authorities according to competition laws. In this way, KFTC can put forward suggestions in some necessary circumstances to ensure that government behaviors not excessively restrict competition.

In fact, competition evaluation system has been established in many countries. For instance, article 85 of the Hungarian Competition Act provides that where in the course of its operation the Hungarian Competition $\mathrm{Au}-$ thority finds that any public administrative resolution violates the freedom of competition, it shall request the public administrative body to amend or withdraw the resolution in question. Where such a public administrative body fails to comply within 30 days with the request, the Hungarian Competition Authority may seek a court review of the resolution of such a public administrative body violating the freedom of economic competition, except in cases where the law excludes a court review of such public administrative resolutions. In Mexico, the Federal Competition Commission (FCC) is required to make an assessment of the competition conditions or substantial market power in certain regulated sectors before the regulator can impose price controls. Furthermore, in several government processes and procedures, including privatizations, tenders, auctions, permits, concessions, and licenses, the participants or applicants must obtain a favorable opinion from the FCC as a clearance prerequisite. In addition to the above, the FCC can issue opinions and recommendations regarding the effects on competition of proposed and existing laws, regulations and other government acts, such as the terms of reference for privatizations and auctions [30]. All these measures ensure that the governmental economic intervention under economic recessions will not distort competition structure, thus play a role of competition maintenance.

Overall, many countries have absorbed painful lessons brought by relaxing competition policy during economic downturns, and gradually realize that effective competition and competition policy can aid economic recovery. 
Besides, after years of experience of competition policy enforcement, the status of competition policy in many countries has been raised significantly. All these factors have prompted the changes of competition policy.

\subsection{The Mechanisms Supporting the Changes of Competition Policy}

In western countries, the changes of competition policy also based on some corresponding mechanisms which ensured the implementation of a series of economic stimulus policies would not overly distort the market competition structure.

Despite of the diversification of competition policies adopted by different jurisdictions during the current crisis, it still can be seen that the western countries always alter competition policies by the means of democratic legislation. The appearance of all kinds of economic stimulus plans also experienced democratic legislative procedures. For instance, the US Emergency Economic Stabilization Act was rejected originally when it was submitted to the House of Representatives. It was passed until it added multiple measures strengthening the interest of taxpayers. In contrast, all of the China's economic stimulus plans were only passed by the State Council, and never have been submitted to the legislature for further discussion. Furthermore, the details of these plans have not made known to the public. The government explained that "relevant departments will continue to improve the contents (of economic stimulus plans) according to the decision of the Executive Meeting of the State Council, and because of the launch of industrial policies involves many departments, it will make public in succession until relevant policies go through further assessment and consultation [31].” This undoubtedly weakened the legitimacy and persuasiveness of economic stimulus plans.

In western countries, there are also coordination and supervision mechanisms between competition policy and other economic stimulus policies. For instance, the European Commission is responsible for the competition policy review to state aid measures applied by member states, and the US DOJ carries out competition policy review to the government's economic stimulus measures stipulated in different Acts of the Congress. But in China, there are no cases or signs show that industry policy can be or will be reviewed pursuant to competition policy. In fact, China did establish a monitoring security system in terms of a variety of special projects for the purpose of expanding domestic demand. However, compared to the US mode of monitoring which was conducted by both of the legislature and the executive, China's monitoring system was definitely confined within the administrative system, which lead to a great doubt on the effectiveness of monitoring results. Furthermore, there has been no case that specific sectors were reviewed by competition policy in China, and as an enforcer of both competition policy and industry policy, the capability of the National Development and Reform Commission (NDRC) to balance the two is still in great doubt.

In addition, from the view of effective enforcement, any policy should only exist in a certain period of time. Industrial policy may be effective at a certain time, but after such time it may become invalid instead [32]. Indeed, China's ten industry adjusting and reinvigoration programs were valid only in three years (from 2009 to 2011). However, all resources released to the public will inevitably form interest groups. The investments and assistances from the government are bound to change the market structure, too. Once interest groups were formed and market structure was fixed, it would be quite difficult to restore it to original state. More importantly, financial crisis may soon be past. According to a report from the National Association for Business Economics, while the economy is showing signs of stabilizing, the recovery will be more moderate than is typical following a severe downturn [33]. However, the inherent structure formed by government investments has been difficult to reverse. Considering that the economic stimulation was led by the government, more attention should be paid to government intervention and following monopolistic conducts. Otherwise, once the crisis subsides, the formation of monopolistic market structures and accompanying economic interest groups will constitute a strong obstacle to sustained and healthy development of economy.

The western countries' insistence of competition policy in this current crisis is also related to their religiousness to free market. On the surface, the outbreak of the financial crisis exposed the shortcomings of the market itself. However, a vast majority of the existing literature suggest that the financial crisis is due to the absence of financial supervision rather than originating from market failure [3]. At the EU level, it is the goal to establish and maintain an EU unified market guide to the enforcement of EU competition law. Competition policy has become an effective means to achieve the "European interest". EU needs to take into account the different levels of its member states in the economic development and their extent to which the economy was affected by the financial crisis. Therefore, on the one hand, it is necessary to achieve a coordinated response in order to guarantee the legitimacy and effectiveness of remedial measures adopted at national level; on the other hand, it must prevent the destruction of EU competition rules by national enforcement, making the member states consider the "European interest" in dealing with the economic crisis. In this context, the requirement that the basic principles and rules being unchanged while the implementation can be relatively flexible naturally become the first choice of EU competition policy. 
Unfortunately, China has not recognized that excessive government intervention in the economy may result in serious consequences. More seriously, there are no free market tradition and no impulse of competition review in China, which would undoubtedly lead to the silence of competition policy enforcers during times of crisis. Although in the legal level, China already has the Antiunfair Competition Law and the Anti-monopoly Law, but the philosophy of competition policy enforcement and the effect of competition policy enforcement are obviously poor. Taking into account that there was only a very short history of China to have laws and regulations in terms of competition, while government intervention in the economy is a traditional practice, there is still a long way to go to make competition policy play its fundamental role in economic decision-making.

\section{The Choice of Competition Policy during Economic Recessions}

\subsection{The Goals of Competition Policy during Economic Recessions}

In many people's eyes, in order to alleviate economic recessions, stimulate employment and restore market confidence, the government's emergency rescue and direct intervention are inevitable. For example, some people think that promoting merger transaction is "a way of the government and institutional investors (to defuse financial crisis) in the current situation” [21]. In China, some scholars also believe that the industrial policy is a top priority during financial crisis and the decisions made according to the Anti-Monopoly Law shall be reviewed in the light of industry policy [34]. However, these people failed to see the limitations of government intervention. Government intervention is to overcome the market failure. Once the market mechanism plays its due role again, the government should timely exit. In fact, once the government intervenes in the economic operation, it is difficult for those enforcers who have been benefited from the intervention exits voluntarily. Under China's government-led economic system, it is foreseen that the government failure would be more outstanding than market failure, thus the government's undue interference in economy will definitely form long-term effect on the market mechanism.

In essence, competition policy is also one of means used by governments to regulate economy. But it operates in a different way with other regulatory means carried out by the government. The beliefs to free competition, which will no doubt form reaction to other ways of governmental controls, are the premise of competition policy. These reliefs and their reactions to other governmental policies, make competition policy a firewall ensuring the normal operation of market mechanism and preventing market structure from eroding by other economic policies (such as industrial policy, financial policy, tax policy and trade policy) during recession periods. By ensuring that all kinds of intervention measures operate within the scope of market failure and maintaining the benign competition mechanism of market economy, competition policy realizes the biggest social interest.

To sum up, in economy downturns, competition authorities should hold on the bottom line of competition policy to ensure that other economic policies will not become the substitutes of competition policy. But competition policy during economic recessions also need not expand its battle line. Because the implementation of competition policy is also a way of government interference in the economy, thus its operation still should uphold the bottom line of market failure. In brief, in economic recessions, competition policy should act as a firewall of the market mechanism which forms effective checks and balances with other economic policies, and adheres to the goals of competition policy as usual. Even it has to take some flexibility on the enforcement, it should be applied within the existing policy framework as the following text sets forth.

\subsection{The Flexible Enforcement of Competition Policy during Economic Recessions}

In fact, the competition law itself has provided many tools to apply competition policy flexibly during economic recessions. For example, the competition law always contains some exception and exemption provisions, which typically represents the mutual compromise between competition policy and other economic policies. These exemptions have become the main basis for flexible application of competition policy during economic downturns. Among them, the exemptions for specific cartels and anti-competitive concentrations have been the two major mechanisms directly related with economic recessions. Besides, the flexible application of competition policy during economic recessions can also be reflected by the coordination between competition laws and industrial laws as well as competition authorities and sector regulators. What kind of laws shall take priority during economic downturns and what degree of cooperation between different enforcers shall be carried out determine directly the effectiveness of competition policy.

\subsubsection{Exemption of Cartels}

Exemption of cartels means that specific cartels could be exempted from the application of competition law if they meet certain public interest conditions. For example, paragraph 1 of article 15 of the Anti-Monopoly Law of China (AML) provides that an agreement among business operators shall be exempted from application of articles 13 and 14 if it can be proven to be in any of the 
following circumstances: 1) for the purpose of improving technologies, researching and developing new products; 2) for the purpose of upgrading product quality, reducing cost, improving efficiency, unifying product specifications or standards, or carrying out professional labor division; 3) for the purpose of enhancing operational efficiency and reinforcing the competitiveness of small and medium-sized business operators; 4) for the purpose of achieving public interests such as conserving energy, protecting the environment and relieving the victims of a disaster and so on; 5) for the purpose of mitigating serious decrease in sales volume or obviously excessive production during economic recessions; 6) for the purpose of safeguarding the justifiable interests in the foreign trade or foreign economic cooperation; or 7) other circumstances as stipulated by laws and the State Council. The cartels between small and medium-sized business operators stipulated in 3), the public interests cartels stipulated in 4), economic recession cartels stipulated in 5) and foreign trade or foreign economic cooperation cartels stipulated in 6), all may be objects of exemption during economic recessions. In particular, economic recession cartels are the most common type of immunity during recessions.

Economic recessions may arise from economic cyclical changes or economic structural changes. Economic cyclical changes signify the repeated changes of economy from prosperity to decline, and economic structural changes show "a particular sector in a state of crisis due to lack of comparative advantage" [35]. In the face of cyclical recessions, almost all industries would be affected so that the economy is under attack of "systemic risk". However, structural recessions only come from overproduction or insufficient demand of certain industries so that the extent of the recession is relatively weaker than cyclical recessions. But whatever the causes of depression, it will definitely make a lot of enterprises eliminated from the market and result in substantive waste of resources and social problems (such as the unemployment problem). In this case, allowing cartels between enterprises can at least partially ease the crisis. However, there is no doubt that recession cartels are still typical anti-competitive behaviors for the reason that allowing enterprises signing anti-competitive agreements during recessions will result in the survival of low efficiency manufacturers and hurt those efficient manufacturers who can survive no matter how the market changes [36]. So in considering the exemption of recession cartels, it still needs to meet certain conditions.

First of all, competition authorities need to consider whether the economic recession has reached a serious degree that makes cartel "essential" for the economy recovery. Secondly, the standard of proof should be different for different kind of recessions. The proof requirements of exemption for structural depressions should be stricter than that of cyclical recessions. This is because the influence of structural depressions on economy is relatively smaller than cyclical recessions and structural depressions are often triggered by the industry support of governments which is likely to distort market structure more severely [37].

Third, the exemption of cartels should be granted to "efficient" enterprises, that is namely, in the general market competition condition they will not be eliminated, but the economic recession may rule them out of the market with other non-efficient enterprises. The reasonableness of recession cartels is based on the fact that non-efficient enterprises will be eliminated from the market under cyclical economic crisis so that the balance between the aggregate demand and the aggregate supply of the society will be regained, but when the crisis is especially serious, even efficient enterprises may go bankrupt and lead to the plight of destruction of the whole industry. In other words, it is only an expedient measure to allow such enterprises reaching cartels because it will not constitute a substantial distortion to the market.

Finally, the exemption of recession cartels shall meet the conditions as prescribed by competition laws. For example, according to article 15 of AML, cartels could not be exempted except that the business operators prove that the agreement can enable consumers to share the interests derived from the agreement, and will not severely restrict the competition in relevant market.

\subsubsection{Defense of Concentrations}

In economic recessions, business operators can also allege the legitimacy of concentration with the aid of the defense provisions of competition laws. For example, Article 28 of the AML provides that "where a concentration has or may have effect of eliminating or restricting competition, the Anti-monopoly Authority under the State Council shall make a decision to prohibit the concentration. However, if the business operators concerned can prove that the concentration will bring more positive impact than negative impact on competition, or the concentration is pursuant to public interests, the Anti-monopoly Authority under the State Council may decide not to prohibit the concentration." In this article, "more positive impact than negative impact on competition" (competition defense) and "public interests" (public interests defense) are typical justifications for concentration.

Competition defense is simply reviewing the effects of concentration on competition. Although some concentrations may result in elimination or restriction of competition (in a sense, any concentration has this result), they may in fact promote a more fair, orderly and effective competitive market. For instance, the concentration between two enterprises in a market of excessive competi- 
tion, or the concentration between a big enterprise outside the relevant market and a small enterprise inside the relevant market, can both improve the market competition condition.

Public interests defense is reviewing the non-competition effects of concentration. Sometimes, competition policy goals have to give way to other policy goals for the consideration of public interests. Therefore, it becomes necessary to form principles and rules on how to balance the competition and the public interests. However, it is worth noting that the AML has increased the difficulty of public interest defense because it only mentions it but does not make any explanation or enumeration. Public interest itself is a very abstract concept with great uncertainty, so many jurisdictions have generally enumerated conditions to apply it. These conditions mainly include efficiencies, failure and existing assets, improving international competitiveness, concentration in small market, concentration among small and medium-sized enterprises, etc. Among them, the efficiency defense and the failure and existing assets defense are the main two justifications enterprises can use to justify concentrations during economic recessions.

The efficiency defense of concentration refers to the process launched by the business operators to demonstrate that the efficiency gains arising from the concentration are greater than or could offset the anti-competitive effects, and the operators hereby are entitled to obtain the anti-monopoly exemption. In general, the application of efficiency defense is required to satisfy the following five conditions: 1) the alleged efficiencies must be merger-specific; 2) the alleged efficiencies must be verifiable; 3 ) the alleged efficiencies must be timely to overcome anti-competitive effects; 4) the alleged efficiencies must not grow out of an anti-competitive reduction in output, service, quality and selection; 5) the alleged efficiencies almost never justify a concentration leading to monopoly or near-monopoly. In economic recessions, if enterprises can prove that the concentration can bring significant efficiencies and meet the above five conditions, concentration will be able to get exemption. But the efficiencies of concentration are difficult to measure, so Judge Posner considered that "there should not have universal efficiency defenses" [38]. From this point of view, if the anti-monopoly law was strictly implemented, enterprises would not have big chance to win efficiency defenses.

In contrast, the failure and existing assets defense is more easily to be successful during economic recessions. The depressed economy will make many enterprises on the verge of bankruptcy, and through the mergers and acquisitions, at least the assets of the acquired enterprises still remain in the market. Compared to bankruptcy, the concentration does not lessen competition, but brings the effective utilization of resources. Therefore, competition authorities will usually accept this defense during economic recessions. From the view of efficiency, the bankruptcy will definitely cause certain net losses, but merger can avoid such losses. Such efficiency produces enough justifications to allow the concentration. Besides, under this kind of circumstance, although the falling firms may make acquirers more strong, the anti-competitive effects are insignificant [39]. Therefore, the failure and existing assets defense is a good justification for concentration during economic recessions.

\subsubsection{The Priority of Application: Competition Laws versus Industrial Laws}

The effective enforcement of competition policy during economic recessions also needs to deal with the relationship between competition laws and sector laws, including which shall prevail in times of economic recessions, how to allocate the jurisdiction of competent competition authorities and sector regulators, and how to resolve disputes when conflicting.

Basically, there are two ways of competition policy in terms of the coverage in economy. The one is that the competition policy uniformly applies to all areas of economic activities in a country, and then may grant exemption to enterprises according to specific "public interest" conditions. The other is that the competition policy only can be applied in a limited area and when it conflicts with other policies, it has to make concessions. Developed jurisdictions such as the United States and the European Union mostly adopt the former, while China, according to relevant regulations and some practices, adopt the latter. There are several antitrust rules in China's relevant laws and regulations such as the Price Law, the Tenders and Bids Law, the Railway Law and the Telecommunications Regulations. According to the principle of lex specialis derogat legi generali, these sector laws and regulations would lead to the enterprises established pursuant to these laws and regulations not regulated by the AML and make no use of competition policy.

Especially, the Article 7 of AML provides that, "with respect to the industries controlled by the State-owned economy and concerning the lifeline of national economy and national security or the industries implementing exclusive operation and sales according to law, the state protects the lawful business operations conducted by the business operators therein. The state also lawfully regulates and controls their business operations and the prices of their commodities and services so as to safeguard the interests of consumers and promote technical progresses." There is no doubt that a large number of natural monopoly industries and policy monopoly industries belong to "the industries controlled by the State-owned economy and concerning the lifeline of national economy and na- 
tional security or the industries implementing exclusive operation and sales according to law”. Once these industries were entirely ruled out of the application of AML, it will seriously hinder the regulation reform of related industries and the sustainable development of economy. Therefore, in order to improve the socialist market economic system and form effective competition in most industries, China should make clear that the AML shall apply to the whole economy. It is recommended to refer to the experience of Taiwan's Fair Trade Law, which prescribes that the priority of application of special laws shall not contravene the legislative purpose of competition laws.

The effective implementation of competition policy is also necessary to allocate equitably the jurisdiction between competition authorities and sector regulators. In the worldwide, there are basically three kinds of modes on the allocation of competition review powers between competition authorities and sector regulators. The first mode is the sector regulators enjoy exclusive jurisdiction; the second mode is competition authorities enjoy exclusive jurisdiction; and the last one is that the competition authorities and the sector regulators share jurisdiction simultaneously. In fact, the relations between antitrust laws and sector regulations fundamentally depend on the competition level of relevant industries [40]. In China, considering that competition authorities have been established for only several years while sector regulators have existed for many years, it is highly likely to lead to an insufficient application of competition policy if depending on sector control too much. But it will also give rise to the problem of information asymmetry if competition authorities take charge of competition control solely. So in comparison, China is more suitable to adopt the mode of sharing jurisdiction between competition authorities and sector regulators.

However, shared jurisdiction is likely to have consequences of repeated regulation or non-regulation. Therefore, it is necessary to identify the exclusive jurisdiction of competition authorities and sector regulators respectively. It is suggested that in the premise of the general application of the AML to the economic activities, sector regulators shall have the supplementary regulation power on abuse of a dominant position and monopoly agreements, and in some extremely specific situations, they may exercise regulation power exclusively; but the competition authorities shall have the power to review concentrations exclusively in any cases [41]. This is because competition authorities do not have advantages on information and could not regulate ex ante compared with sector regulators in terms of the abuse of dominant position and monopoly agreements, while in terms of concentration review, competition authorities are much more professional.
Therefore, competition authorities shall enjoy an exclusive jurisdiction over concentration cases, unless the concentration is related to non-competition issues such as national economic security in which case other institutions may have the power to intervene. As for the regulation of abuse of dominant position and monopoly agreements, it is more viable to form a sharing jurisdiction mechanism. But it still needs to establish a corresponding coordination mechanism between competition authorities and sector regulators on how to share regulation powers.

The coordination mechanism between competition authorities and sector regulators should at least include two contents. First, during their law enforcement process, both sides should give each other fully understanding and support. Sector regulators have more advantages in the cost calculation, information collection and timely intervention, while competition authorities have more advantages in the experience of competition law enforcement. So in order to make full use of their respective advantages, on the one hand, for some sector-specific technical problems, competition authorities should consult the opinions of competent sector regulators; on the other hand, when sector regulators are processing competition cases involving competition issues such as the definition of relevant market or the determination of dominant market position, they also should solicit the opinions of competition authorities.

Second, it needs to introduce competition advocacy into the coordination mechanism. Competition advocacy refers to all kinds of measures carried out by competition authorities except for competition law enforcement. Generally, there are two components of competition advocacy: the one is the advocacy aiming at other regulators or related rule makers in order to urge them not to take anti-competitive conducts; the second is the advocacy for all members of the society in order to improve their consciousness of competition. The competition advocacy mechanism said here mainly refers to the former. In fact, the proposed draft of the AML on July 27, 2005 once stated that "the anti-monopoly law enforcement authority shall have the right to put forward revision suggestions to policies and regulations involving anti-monopoly issues enacted by other government departments". But it was finally cancelled in the AML which leads to a blank of coordination mechanism in competition legislation. In practice, a lot of countries have formed the competition advocacy mechanism. We suggest that competition authorities shall be granted the power to make suggestions to other government department (especially sector regulators) on regulations and policies relating to competition policy. Besides, Sector regulators shall consult with competition authorities in advance when they plan to enact or amend regulations and policies involving competition policy. 


\section{Conclusions}

Economic recessions throughout the history were always accompanied by relaxation or abandon of competition policy, but today's crisis is not experiencing substantive recession of competition policy enforcement in major countries and regions. On the contrary, most jurisdictions have clearly expressed the determination to strengthen competition policy enforcement during the financial crisis. Even in the countries where the market stability and confidence is considered to be more important than the maintenance of competitive market structure, it is to amend the existing competition policy by way of legislation instead of administrative decisions. The enforcement of competition policy, especially the AML in China has just started, but the government intervention represented by the implementation of industrial policies has had a long history. In the current financial crisis, in order to prevent systemic risk that may be aroused by excessive government intervention, a more effective competition policy enforcement should be adhered to. In fact, both historical practice and theoretical explanation have indicated that it is much more reliable to take advantage of market competition to offset the negative impact caused by the strengthening of supervision and expansion of intervention by the government.

Therefore, during recessions, if the government invests heavily to stimulate economic recovery, it has to be vigilant in the following aspects. First, the bottom line of government intervention is market failure. Once the market mechanism has recovered, the government should exit automatically because the damage caused by government failure is much greater than market failure. Second, competition policy enforcement should involve coordination and monitoring mechanisms. On the one hand, various economic stimulus plans should coordinate with each other and subject to supervision of competition law; on the other hand, the competition policy and other economic policies should also be enforced based on the establishment of coordination mechanisms. Finally, under the current regime in China, the government should pay particular attention to government-led anti-competitive behaviors. By means of "choosing the winner", current industrial policies attempt to drive economic growth in the short term, but such approach is likely to distort market structure, and in the long term impede the sustainable development of economy.

In conclusion, in the face of the strengthening of government's direct control and macro-economic intervention in crisis, it becomes more necessary for competition policy to maintain a firewall to secure market competition and prevent the negative impact brought about by the supervision and regulation strengthened by the government. Considering China's short history of competition policy enforcement and consistent tradition of gov- ernment intervention in the economy, in the current circumstances, more effective competition policy enforcement should be adopted, and more attention should be paid to government-led anti-competitive conducts which may bring about distortions and negative effects to competitive market structure.

\section{REFERENCES}

[1] D. Crane, "Antitrust Enforcement during National Crises: An Unhappy History,” 2008. http://www.globalcompetitionpolicy.org

[2] M. Nuemann, "Competition Policy: History, Theory and Practice,” Peking University Press, Beijing, 2003, p. 31.

[3] C. Shapiro, "Competition Policy in Distressed Industries,” In: Remarks as Prepared for Delivery to ABA Antitrust Symposium: Competition as Public Policy, 2009. http://www.justice.gov/atr/public/speeches/245857.pdf

[4] J. M. Burns, J. W. Peltason and T. E. Cronin, "Government by People,” China Social Science Publishing House, Beijing, 1996, p. 121.

[5] W. E. Leuchtenburg, "The Supreme Court Reborn: The Constitutional Revolution in the Age of Roosevelt," Oxford University Press, Oxford, 1996.

[6] Appalachian Coals v. US, 288 US 344, 1933.

[7] D. J. Gerber, "Law and Competition in Twentieth Century Europe: Protecting Prometheus," China Social Science Publishing House, Beijing, 2004, pp. 182-201.

[8] M. Nuemann, "Competition Policy: History, Theory and Practice,” Peking University Press, Beijing, 2003, p. 52.

[9] H. Toshifumi, “Japan's Competition Policy and Competition Law,” Economic Law Forum, Vol. 10, No. 1, 2005, p. 52.

[10] K. Yoshio, “Introduction to Economic Law,” China Legal Publishing House, Beijing, 2005, pp. 243-245.

[11] Y. F. Sun, "Industrial Policy and Competition Policy in Economic Development-Analysis of Japan and Its References,” Weekly Market (Theoretical Research), No. 2, 2007.

[12] J. Chen, "South Korea's Economic Reforms after Asian Financial Crisis,” China Opening Herald, No. 4, 2003.

[13] D. Balto, "Restoring Trust in Antitrust Enforcement," 2009.

http://www.americanprogress.org/issues/2009/05/antitrust _enforcement.html

[14] L. C. Overton and R. C. Thomas, “Antitrust Enforcement in the Obama Administration,” 2009. http://www.jonesday.com/pubs/pubs_detail.aspx?pubID= S6176

[15] Justice Department Withdraws Report on Antitrust Monopoly Law, 2009.

http://www.usdoj.gov/atr/public/press_releases/2009/245 710.htm

[16] Y. X. Li, "Five Electronics Manufacturing Enterprises of Japan and South Korea Were Penalized Severely by the JFTC,” 2009. 
http://news.sohu.com/20091008/n267198496.shtml

[17] Communication from the Commission, “Temporary Framework for State Aid Measures to Support Access to Finance in the Current Financial and Economic Crisis,” 2009. http://eur-lex.europa.eu/LexUriServ/LexUriServ.do?uri= CELEX:52009XC0407(01):EN:NOT

[18] Communication from the Commission, "Amendment of the Temporary Framework for State Aid Measures to Support Access to Finance in the Current Financial and Economic Crisis,” 2011.

http://ec.europa.eu/competition/state_aid/legislation/atf_e n.pdf

[19] N. Kroes, "EU State Aid Rules_Part of the Solution," 2008.

http://ec.europa.eu/competition/speeches/index_2008.htm

[20] Id.

[21] K. Ravichandran, "Effect of Financial Crisis over Mergers and Acquisitions in GCC Countries,” 2009. http://ssrn.com/abstract=1360249

[22] Decision by Lord Mandelson, the Secretary of State for Business, Not to Refer to the Competition Commission the Merger between Lloyds TSB Group plc and HBOS plc under Section 45 of the Enterprise Act 2002, 2008. http://www.berr.gov.uk/files/file48745.pdf

[23] Ministry of Industry and Information Technology, "Emergency Communications on Curbing the Over-Fast Increase of the Output of Iron and Steel Industry”, 2009. http://www.miit.gov.cn/n11293472/n11293832/n1129390 7/n11368223/12344536.html

[24] The Shaanxi Provincial Government, "Implementing Guidelines on Speeding up the Merger and Reorganization of Coal Enterprises,” 2008.

http://law.baidu.com/pages/chinalawinfo/1702/25/1be897 22232eab41550137b35a5daf0e_0.html

[25] J. Powell, "Did the New Deal Actually Prolong the Great Depression?” 2002.

http://www.heartland.org/custom/semod_policybot/pdf/1 2789.pdf

[26] H. L. Cole and L. E. Ohanian, "New Deal Policies and the Persistence of the Great Depression: A General Equilibrium Analysis," Journal of Political Economy, Vol. 112, No. 4, 2004. doi:10.1086/421169

[27] Id, fn. 8.

[28] C. Varney, "Vigorous Antitrust Enforcement in this Challenging Era," Remarks as Prepared for the Center for American Progress, 2009. http://www.usdoj.gov/atr/public/speeches/245711.htm

[29] X. Q. Feng and J. Wang, "From Industrial Policy to
Competition Policy: The Intervention Mode Transformation of East Asia Governments and Their Revelation to China,” Nankai Economic Studies, No. 5, 2005.

[30] O. Solano, R. del Villar and R. Garcia-Verdu, "Challenges to the Effective Implementation of Competition Policy in Regulated Sectors: The Case of Telecommunications in Mexico,” Northwestern Journal of International Law \& Business, Vol. 26, No. 3, 2006, pp. 527-546.

[31] SINOLINK Securities, "Special Reports on the Top Ten Industrial Revitalization Plans,” 2009.

http://www.p5w.net/stock/lzft/scyj/200902/P0200902045 23856325414.pdf

[32] X. R. Zhang, “The Effectiveness of Industrial Policy under the Condition of Market Economy from the Experiences of America and Japan," Rural Economy and Technology, No. 3, 2007.

[33] Economists, "Recession to End in 2009," CNN Money, 2009.

http://money.cnn.com/2009/05/27/news/economy/NABE _recovery_outlook/index.htm

[34] Y. S. Xiao, “The International Financial Crisis and the Implementation of the Anti-Monopoly Law in China: From the Perspective of the Relationship between Competition Policy and Industrial Policy \& Trade Policy," Journal of Shijiazhuang University of Economics, No. 4, 2009.

[35] W. S. Lin, "Legal Analysis on the Conflict Coordination System of Competition Policy and Industrial Policy," China Financial and Economic Publishing House, Beijing, 2005, p. 74.

[36] M. Motta, “Competition Policy: Theory and Practice," Shanghai University of Finance \& Economics Press, Shanghai, 2006, p. 18.

[37] M. Nuemann, “Competition Policy: History, Theory and Practice,” Peking University Press, Beijing, 2003, p. 128

[38] R. A. Posner, “Antitrust Law,” China University of Political Science \& Law Press, Beijing, 2003, pp. 155-159.

[39] G. Y. Xu, "Competition Law Analysis on the Combination Behaviors of Enterprises," Present Day Law Science, No. 1, 2006.

[40] H. Ullrich, "The Evolution of European Competition Law: Whose Regulation, Which Competition?” Edward Elgar, Northampton, 2006.

[41] Z. J. Zhang, “The Construction of the Relationship between the Anti-Monopoly Law and the Industry Supervision System: From the Perspective of Regulation on AntiCompetitive Behaviors in Natural Monopoly Industries," Contemporary Law Review, No. 1, 2009. 